\section{The European Research Council}

\author{
Thomas König \\ Cambridge/Malden 2017: Polity Press, 240 Seiten.
}

Rafael Y. Schögler

Department of Translation Studies, University of Graz, Austria

E-Mail: rafael.schoegler@uni-graz.at

For science, the creation of the European Research Council (ERC) is probably the most impressive and impactful instance of institution building within the parameters of the European Union.

In his book, Thomas König provides unprecedented insights into the creation process of this institution, which was established to years ago. He describes political battles, administrative fine-tuning, necessary compromise, but also the side-lining of certain actors and agendas within the creation phase of this research funding instrument. His insights are based on his privileged access to first-hand information and individuals involved in this process on all levels. As former scientific advisor to the second president of the ERC (Helga Nowotny), König could not only observe and participate in the establishment of this institution, but also took the task upon himself to reconstruct the multiple realities of the creation of the ERC by interviewing manifold actors involved in this process and viewing, organizing and analysing their personal archives. His direct access to institutions and agents is particularly valuable considering that there is little tradition within the European administrative bodies of archiving material in a comprehensive and well-organized manner. For unofficial documents, personal annotations and other behind the scene documents, the historical archives of the European Commission and the Historical Archives of the European Union in Florence (HAEU) rely heavily on the occasional habit of high-ranking officials and advisors, to hand on their personal files at the end of their career which makes them a difficult resource for the interested scholar.

Although the continuous efforts of single individuals and more organized groups over a long period of time cannot be underestimated in shaping the institution we have now come to know as the ERC, König points to the momentum created by the Lisbon strategy as a largescale political decision that turned research policy into a central element of the Union's political debates and public discourse. Proponents of an independent European research funding agency recognized the potential of this turn by European policy-makers and built a broad coalition of national funders, disciplinary and inter-disciplinary interest organisations as well as highly-renowned researchers to "feed" the narrative and stay on the political agenda. König identifies the creation of the notion of "frontier research" as an ice-breaker used to enter the European stage and deflect from established cornerstones of Brussels-led research policy (such as "juste retour"). The narrative said that closing the (economic) innovation gap between Europe and other parts of the world could only rely on building and sustaining the European research landscape from a politically independent institution dedicated to identifying highrisk, high-gain projects and highly talented researchers.

König offers a refreshing account of a European policy process without overburdening the reader with EU jargon and abbreviations, which are the DNA of any European Commission document. Describing the research funding instruments bundled in the ERC must have seemed considerably easier after having accomplished to disentangle EU-lingo. Compared to the hundreds of programmes run by the US-American National Science Foundation (NSF) - an institution König and others repeatedly use as a comparative benchmark for the ERC - the funding streams are blatantly simple and straightforward. At the beginning, two main strands of funding were installed: One for established scholars and one for 
newcomers to the academic sphere. After an initial phase of establishing the ERC, it was the second strand that received more attention from within the institution. Providing young scholars with long-term, individual research grants premised the potential to disrupt established paradigms, but also local hiring procedures and national science policy. This aim, however, depends upon holding the promise of funding excellent research alone. This promise was kept by establishing an efficient, politically independent and (comparatively) transparent peer-review process, which is often referred to as a "gold standard". This, combined with the ERC's independence in directing funds with regard to equal treatment of all member countries, provided the ERC with the scholarly recognition it needed to establish itself sustainably. Yet, distributing funds based on the criterion of excellence only, led to unequal allocations between member countries. König explains how this issue was dealt with in the planning phase as well as in the further implementation of the ERC.

This book will be valuable to all those interested in understanding the intricate relationship of different actors within European Union research policy. It is directed at a scholarly and political audience that wants to know more about the political and institutional setup as well as the (initial) logics that governed the European Research Council. All those looking for a personal diary holding notes of undocumented deals, delicate details of behind the scene political bargaining or even personal implications will be disappointed. The book sticks to facts and the reconstruction of different views concerning the political negotiations leading to the establishment of the ERC. The style is straightforward and for the most part descriptive. König refrains from reconstructing the legacy of the "idea" of a European NSF, which goes back at least to the 1970s and has appeared on the political agenda several times since then (for some details see Madsen 2010) and instead concentrates on providing a detailed narrative of the political implementation of the ERC and its initial functioning that is well worth reading.

\section{Literature}

Madsen, Claus (2010). Scientific Europe: Policies and politics of the European Research Area. Multi-Science Publishing, Essex. 